肺癌切除肺の組織学的検索が契機となり診断しえた

健康食品による薬剤性肺炎の 1 例

\author{
陳 啓盛 1 青山克彦 $1 \cdot$ 松島秀和 2 ・ \\ 村井克己 $1 \cdot$ 河端美則 $3 \cdot$ 星 永進 1
}

要旨——背景。肺癌手術組織標本を詳細に検討することは, 肺癌の組織型, 悪性度, 進行度のみでなく, 特発性肺線 維症の存在など背景肺病変の検索にも重要である。今回, 我々は背景肺病変の検索を契機に診断しえた薬剤性肺炎を経 験した．症例. 症例は 72 歳の男性. 右肺癌 cT1N0M0, stage IA と診断し, 右中葉切除術を施行した. 術後第 4 病日に 呼吸困難が出現, 胸部 X 線上右下肺野に術直後には認めなかった新陰影が出現, 抗生剂を投与するも急速に増悪した. 胸部 CT では両肺野に広範なスリガラス陰影を認めた。肺癌切除肺の組織学的検索で急性好酸球性肺炎の所見が得ら れ，気管支肺胞洗浄液でも好酸球比率の増加を認めたため，陰影は急性好酸球性肺炎によるものと推察した。詳細な問 診の結果, 患者は入院前からアガリクス, メシマコブを含む健康食品を服用していたことが判明した. 健康食品の服用 中止のみで自覚症状, 胸部 X 線所見が改善したため, 本症例を薬剤性肺炎と診断した. 結論。肺癌切除肺における背景 肺の組織学的検索が契機となり, 薬剤性肺炎を診断しえた.また, アガリクスなどの健康食品による薬剤性肺炎の報告 例は少ないが，今後も注意すべきである.（肺癌. 2004;44:167-171)

索引用語 一一薬剂性肺炎, 急性好酸球性肺炎, アガリクス, 肺癌手術標本, 健康食品

\title{
A Case of Drug-induced Pneumonia Caused by Health Food and Suspected by the Histologic Examination of the Resected Lung for Lung Cancer
}

\author{
Keisei Chin ${ }^{1}$; Katsuhiko Aoyama ${ }^{1}$; Hidekazu Matsushima \\ Katsumi Murai ${ }^{1}$; Yoshinori Kawabata ${ }^{3}$ Eishin Hoshi ${ }^{1}$
}

\begin{abstract}
Background. Careful examination of resected lung for lung cancer is important not only to know histological typing, degree of malignancy, and degree of progression of lung cancer but also to understand the background lung like coexisting idiopathic pulmonary fibrosis. We experienced drug-induced pneumonia which was found and finally suspected by the histological examination of the background lung lesion. Case. A 72-year-old man was diagnosed to have primary lung cancer cT1N0M0 stage IA, and he underwent right middle lobectomy. He complained of dyspnea on the 4th postoperative day. New shadows appeared in the right lower lung field on chest X-rays, and antibiotics were given but pulmonary shadows rapidly extended. Chest CT showed ground-glass opacities in both lungs. The histologic examination of resected lung tissue revealed the presence of acute eosinophilic pneumonia, and bronchoalveolar lavage fluid showed the increase of eosinophils. We suspected acute eosinophilic pneumonia as the cause of pulmonary shadows. By careful history taking, he admitted that he had taken health food including Agaricus and

埼玉県立循環器・呼吸器病センター 1 呼吸器外科, 2 呼吸器内 科, 3 病理.

別刷請求先：陳 啓盛, 埼玉県立循環器・呼吸器病センター呼吸 器外科, テ360-0105 埼玉県大里郡江南町板井1696 (e-mail: k3699008@pref.saitama.jp).

Department of ${ }^{1}$ Chest Surgery, ${ }^{2}$ Respiratory Medicine, ${ }^{3}$ Pathol-

ogy, Saitama Cardiovascular and Respiratory Center, Japan.

Reprints: Keisei Chin, Department of Chest Surgery, Saitama Cardiovascular and Respiratory Center, 1696 Itai, Konan-cho, Osatogun, Saitama 360-0105, Japan (e-mail: k3699008@pref.saitama.jp).

Received January 22, 2004; accepted April 5, 2004.

(C) 2004 The Japan Lung Cancer Society
\end{abstract}


phellinus linteus before admission. The symptoms and chest X-ray findings improved only on the cessasion of the health food. Therefore, we diagnosed drug-induced pneumonia. Conclusion. We could diagnose drug-induced pneumonia partly by the histological examination of the background change of resected lung. There are a few reported cases of drug-induced pneumonia by health food such as Agaricus, and we must be careful from now on. (JJLC. 2004;44:167171)

KEY WORDS — Drug-induced pneumonia, Acute eosinophilic pneumonia, Agaricus, Resected lung cancer specimen, Health food

\section{はじめに}

肺癌切除標本において背景肺の組織像を詳細に検討す ることは, 間質性肺炎の存在の有無などの評価に役立ち, 術後の治療方針の決定にも重要であると認識されてい る. 1,2 今回, 我々は肺癌切除肺標本の検索を契機とし, 術 前より服用していたアガリタス，メシマコブなどの健康 食品による薬剂性肺炎と診断しえた症例を経験した．若 干の文献的考察を加え報告する。

\section{症 例}

症例：72 歳. 男性.

主訴：呼吸困難（Hugh-Jones II 度）.

既往歴：50 歳時, 十二指腸潰瘍. 65 歳時, 多発脳梗塞. 家族歴：特記すべき事項なし.

契煙歴： 40 本/日（21～72 藏)。入院後に禁煙.

現病歴： 2003 年 5 月, 検診にて胸部異常影を指摘さ れ，6月 6 日に当センターを受診。精査加療目的に 6 月 10 日入院となった。

入院時現症：身長 $167 \mathrm{~cm}$, 体重 $62 \mathrm{~kg}$. 貧血, 黄㾝なし. 表在リンパ節触知せず．胸部聴診上心雑音，ラ音は聴取 せず。チアノーゼ，バチ状指なし。

人院時検查所見：血算,生化学検查に異常所見認めず, 腫瘍マーカーも CEA $5.0 \mathrm{ng} / \mathrm{ml}$, SCC $1.3 \mathrm{ng} / \mathrm{ml}, \mathrm{NSE}$ $12.2 \mathrm{ng} / \mathrm{ml}$ と正常範囲内であった。呼吸機能検查は\% $\% \mathrm{VC}$ 80\%, $\mathrm{FEV}_{1.0} \%$ 96\%，動脈血ガス分析は $\mathrm{pH} 7.41 ， \mathrm{PaO}_{2}$ 83 torr, $\mathrm{PaCO}_{2} 36$ torr, $\mathrm{SaO}_{2} 96 \%$ と両者とも異常は認 ぬなかった。

入院洔胸部 X 線写真: 右中肺野外側に淡い腫瘤影を 認める (Figure 1A).

胸部 CT：在 $\mathrm{S}^{4}$ にスピキュラを伴う $12 \times 10 \mathrm{~mm}$ 大の 腫瘤影を認める。肺門縦隔リンパ節の腫大や両肺野に異 常影は認めなかった（Figure 1B）.

入院後施行した気管支擦過細胞診にて class V と診断 され, 右肺癌 cT1NOM0, stage IA と診断し 6 月 19 日に 右中葉切除, ND2a 郭清を施行した。

術後経過：術後第 4 病日に呼吸困難が出現した。胸部

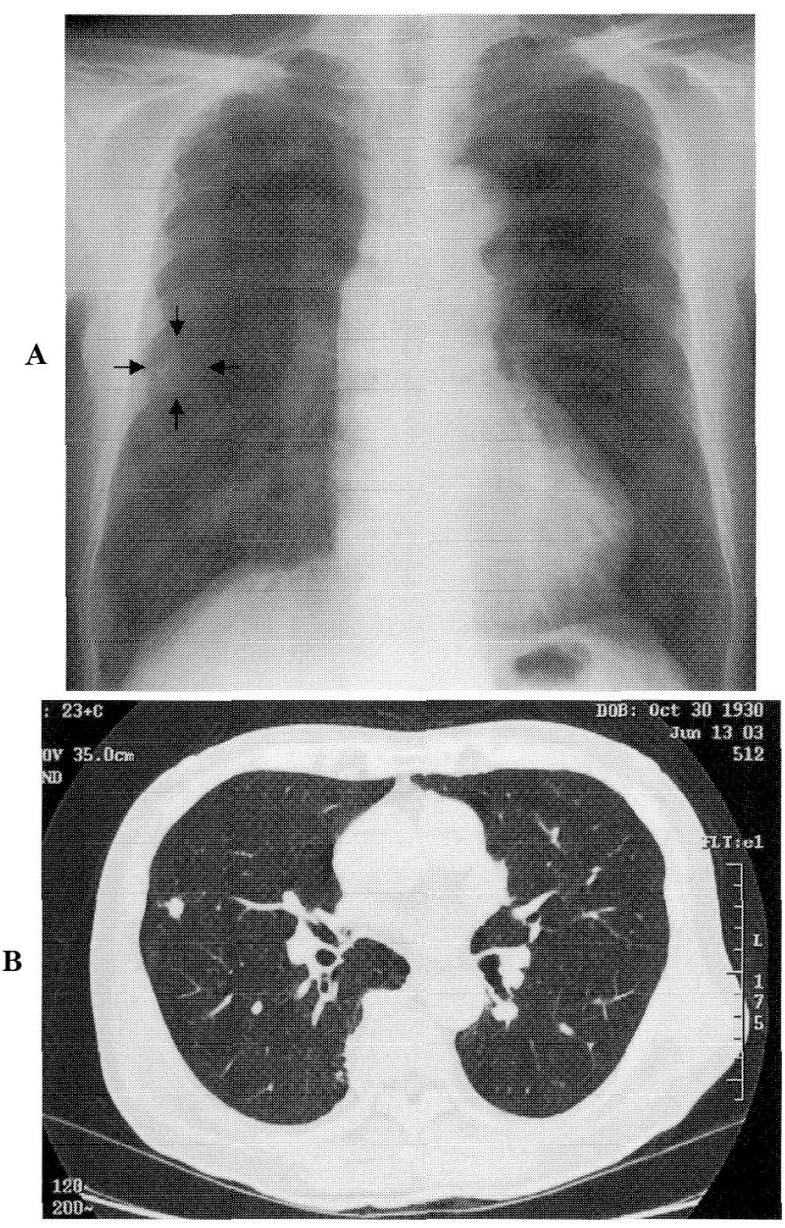

Figure 1. A. Chest X-ray film showing a mass in the right middle lung field. B. Chest CT showed a $12 \times 10 \mathrm{~mm}$ mass with spiculation in right $\mathrm{S}^{4}$.

X 線では右下肺野にスリガラス院影を認め, 肺炎を疑い 抗生剂を投与するも術後第 6 病日の胸部 X 線では㓌影 はさらに増悪し左肺野にも陰影を認めた（Figure 2)．術 後第 5 病日に撮影した胸部 CT では, 右下葉はほぼ全体 に均一なスリガラス陰影を是し右上葉，左肺にも同様な 陰影を認めた (Figure 3A，B)。術後第 6 病日に得られた 手術標本の病理組織所見では, (1)肺癌は $12 \mathrm{~mm}$ 大の 


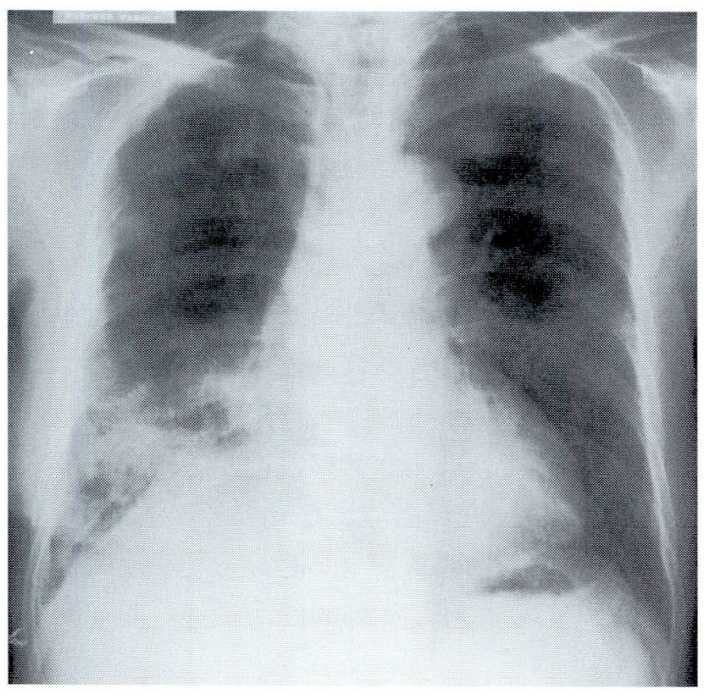

Figure 2. Chest X-ray film on the 6 th postoperative day showing ground-glass shadows in the right lower lung field and the left middle field.
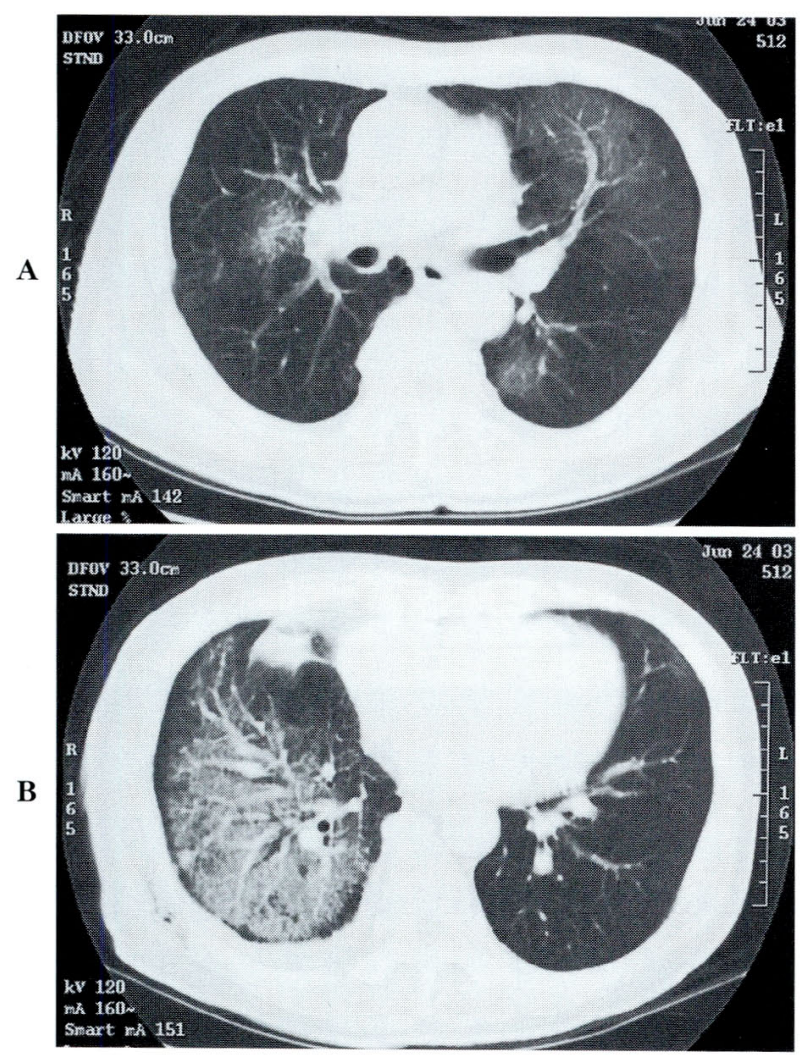

Figure 3. A, B. Chest CT on the 5th postoperative day showed ground-glass opacities in the right lower lobe and in the left lung.

large cell carcinoma (Figure 4A)，(2)腫瘍からやや離れ， 小葉間隔壁で境界された多小葉性の黄色調のコンソリ

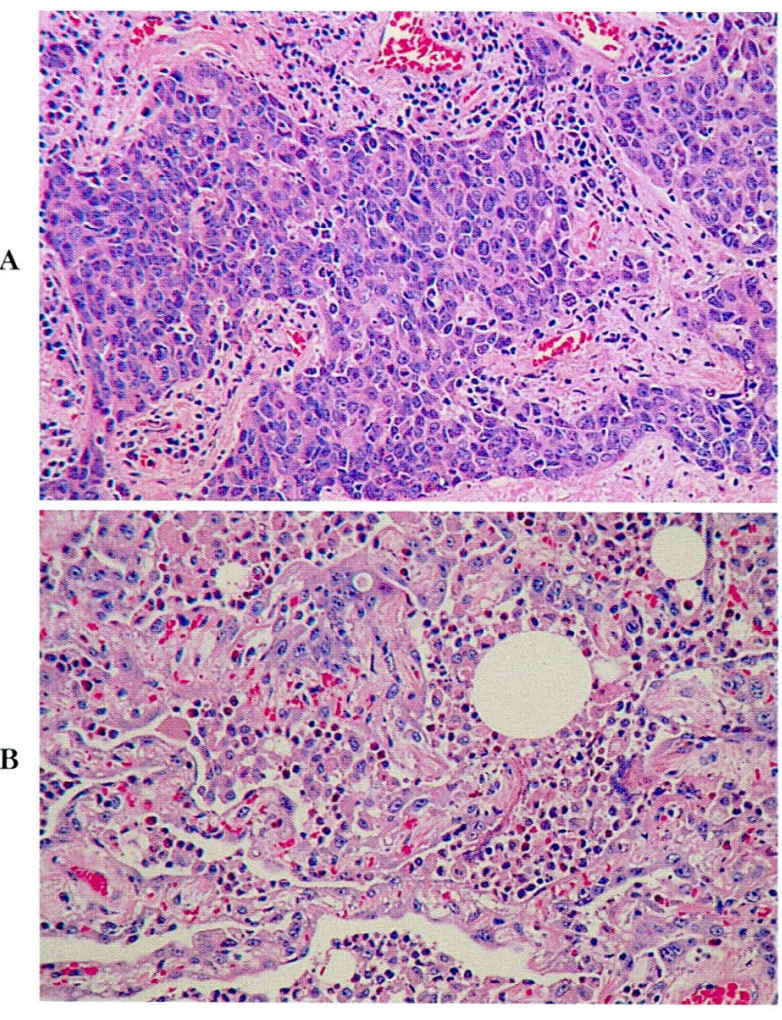

Figure 4. A. Microscopic examination of the tumor revealed large cell carcinoma (HE stain, $\times 20$ ). B. Microscopic examination of lung tissue around the tumor shows interstitial edematous swelling, atypical epithelial regeneration, accumulation of eosinocytes and macrophages, consistent with acute eosinophilic pneumonia $($ HE stain, $\times 20)$.

デーションが認められた．組織学的には小葉間隔壁の浮 腫性肥厚と肺胞壁の浮腫性肥厚, 肺胞上皮の異型再生, ならびに多数のマクロファージと好酸球の滲出からなる 急性好酸球性肺炎（acute eosinophilic pneumonia：以下 $\mathrm{AEP}$ ) 類似の病変であった。 また, 病変部に腫瘍からの壊 死物質の流入はなく，腫瘍内一の好酸球浸潤なども認め られなかった (Figure 4B). 入院後禁煙を続けていること から, AEPの病変を来す原因として第一に薬剤を考え た。詳細な問診を行うと, 入院前日からアガリクス単剂 とアガリクス，メシマコブを含む健康食品を服用，継続 していたことが判明した。術後第 6 病日に施行した気管 支肺胞洗浄液 (bronchoalveolar lavage fluid：以下 BALF) で好酸球比 $11 \%$ と増加し（Table 1), 経気管支肺 生検 (transbronchial lung biopsy：以下 TBLB) でも手術 標本と同様の組織所見が得られた。術後第 6 病日より健 康食品の服用を中止したところ, 徐々に自覚症状, 胸部 $\mathrm{X}$ 線所見は改善した (Figure 5). 未梢血の薬剂リンパ球刺 激試験（drug lymphocyte stimulation test：以下 DLST） 
Table 1. Results of BALF and DLST

\begin{tabular}{|c|c|c|c|}
\hline \multicolumn{2}{|l|}{ BALF (rt. $B^{8}$ ) } & DLST & \\
\hline \multirow{2}{*}{\multicolumn{2}{|c|}{$\begin{array}{l}\text { Recovery } 45 / 150 \mathrm{ml} \\
\text { cell count } 3 \times 10^{5} / \mathrm{ml}\end{array}$}} & Agaricus & 11.1 S.I. \\
\hline & & $\begin{array}{l}\text { The health food including } \\
\text { Agaricus, phellinus linteus }\end{array}$ & 6.1 S.I. \\
\hline Macro & $65 \%$ & & \\
\hline Neu & $15 \%$ & S.1. : stimulatio & n index \\
\hline Eo & $11 \%$ & 1.8 over : & positive \\
\hline Lym & $9 \%$ & & \\
\hline $\mathrm{CD} 4 / \mathrm{CD} 8$ & 1.3 & & \\
\hline \multicolumn{4}{|c|}{ Culture normal flora } \\
\hline \multicolumn{2}{|c|}{ M. tuberculosis $(-)$} & & \\
\hline
\end{tabular}

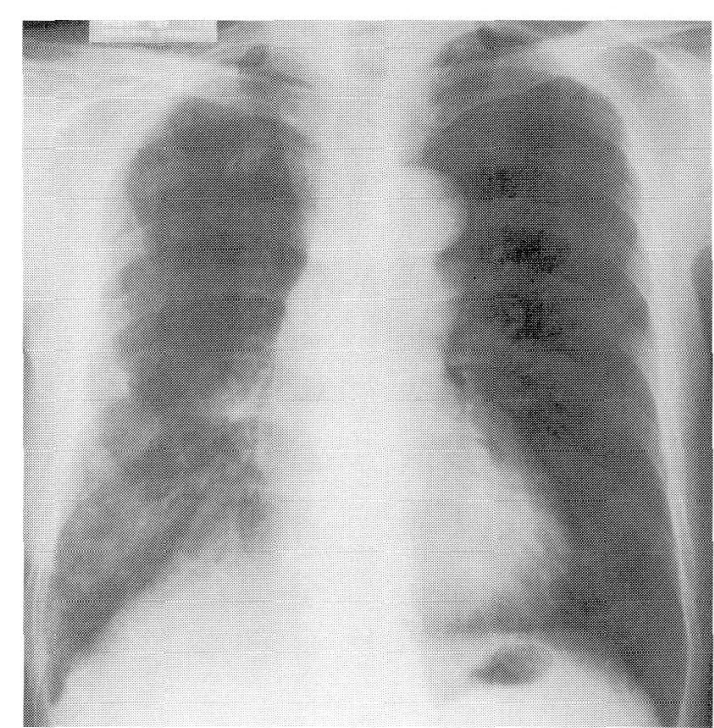

Figure 5. Chest X-ray film at discharge showing the improvement of the shadows.

ではアガリクスとアガリクス，メシマコブを含む健康食 品ともに陽性を示した (Table 1). 以上より本症例を健康 食品による薬剤性肺炎と骖断した。原因薬剤については アガリクス，メシマコブの可能性が考えられるが，チヤ レンジテストの同意が得られず,同定には至らなかった。 術後 18 日目に軽快退院となり, 現在外来通院中だが肺漟 の再発や荣骭性肺炎の悪化は認めていない。

\section{考 察}

今回の症例は背景肺の組織学的検索により, 部分的に 出現した病変を見いだし, それが薬郕性肺炎を疑うきっ かけとなった。本症例は肺癌術後4日目上り呼吸困難を 呈し, 胸部画像上も両側肺の広範にわたり新たな陰影が 出現した. 当初は術後肺炎を考えたが, その後に得られ た切除標本の組織学的所見で腫瘍近傍に限局性の AEP 様病変が認められたため，詳細に問診したところアガリ
クスなどの健康食品の内服歴が判明した。その後の検討 により, (1)健康食品の服用 13 口後に出現した肺病変, (2) 手術時に出現したAEP 様病変は術後に発症した肺炎の 早期病変上考元られ, 術後 TBLB の組織像も同様の所胃 で薬剂性肺炎の組織像として矛盾しない, (3) BALFから 起因菌が同定されず, また抗生剂無效で感染症が否定的, (4)健康食品の術後継続服用で㓌影の広範化, 5)健康食品 の服用中止のみで自覚症状, 胸部 X 線所見が改善, (6)服 用していた健康食品の DLST陽性, が判明し本症例を健 康食品による薬剤性肺炎と骖断した。一般に喫煙に伴う AEP は開始後 1 週間以内の発症が多く, 楽剂性 AEP も 服用 1 21 日㣪での報告がみられる. 3-6 本症例は服用か ら 13 日後の発症で AEP を発症するのに妥当な期間と考 えた。

薬剂によって引き起こされる肺障害の組織像は多彩で ある。また，原因薬剤は以前では抗癌剤，免疫抑制剤が ほとんどを占めていたが, その後抗生物質が増加し漢方 薬, 抗リウマチ薬, 消炎鎮痛剂などが報告され, 現在で はすべての薬郕がその原因となりうる.7,8

病理組織所見としてはdiffuse alveolar damage (DAD), usual interstitial pneumonia, nonspecific interstitial pneumonia, eosinophilic pneumonia, bronchiolitis obliterans organizing pneumonia, hypersensitivity pneumonitis な ど多様であり, 9 これらの組織像が同一個体に混在する ことも多く，それを反映して画像所見も多彩になる。 Akira ら10の薬剂性肺炎 60 例の HRCT の検討によると 小葉間隔壁の肥厚を伴う ground-glass opacity が薬剂性 肺炎の特徴であると報告している。

診断の補助検査としてDLST やチャレンジテスト， ス キンテストなどがあり，中でも現在ではDLST が重要視 されている.DLST は薬剤に感作されたりンパ球が, 抗原 である薬剤と反応し分裂, 増殖する反応を忍用した検查 法である。しかし，安井ら11 はDLSTの結果に偽陽性，偽 陰性が多くみられ, DLSTが陰性であっても原因として 否定できず，陽性であったとしても原因と断定できない と述べている.

治療はまず速やかに服币中の薬殽を中止する必要があ る、アレルギーが関与する場合や急性発㾟型では, 薬剂 の中止により大部分の症例で改善がみられる. 改善のな い場合の治療は副㹂文質ステロイドであり，その有效性 は示されている。しかし, 肺に線維化を来す病態やDAD 症例は予後不良で死亡例も報告されている.12

本症例の画像所見は ground-glass opacity は認めたが, HRCT が施行されておらず, 特徵とされる小葉間隔壁の 肥厚の有無については評椤できなかった。また，組織像 は AEP 類似であることよりアレルギー性が考えられ，原 因薬郕（健康食品）の服用中止のみで自覚症状，胸部 X 
線所見ともに改善した. DLSTでアガリクスは単独でア レルギー陽性を示したが, 健康食品にはアガリクスの他 にメシマコブやビタミン剤など様々なものが含まれてお りアガリクス以外の成分によるアレルギーの可能性も否 定できない.チャレンジテストの同意が得られず原因薬 剽の同定には至らなかった。

現在では様々な薬剤による薬剤性肺炎が報告されてい るが，アガリクスなどの健康食品によるものは少ない. アガリクスなどの健康食品は癌に効果があると新聞や雑 誌などに宣伝され，たくさんの担癌患者が服用している. 健康食品による薬剤性肺炎が存在することを念頭におい て診療することが必要であると考えた.

謝辞：稿を終えるにあたり, 検査, 診断にご協力頂いた, 当セ ンター呼吸器外科の池谷朋彦先生, 呼吸器内科の倉島一喜先 生，杉田裕先生に深謝いたします。

\section{REFERENCES}

1. 河端美則, 福島一雄, 内山隆司, 他. 限局性 usual interstitial pneumonia の存在は diffuse alveolar damage の重要 な危険因子一限局性 UIP 例の急性増悪一. 日呼吸会誌. 2001;39:316-321.

2. 福島一雄, 河端美則, 内山隆司, 他. 限局性慢性間質性肺 炎（限局性 UIP） 127 例の予後：びまん性間質性肺炎への
進展の可能性. 日呼吸会誌. 1999;37:177-182.

3. 妹川史朗, 豊嶋幹生, 千田金吾. 薬剤誘起性好酸球性肺炎. 日胸. 2003;62:1000-1005.

4. Toyoshima M, Sato A, Hayakawa $\mathrm{H}$, et al. A clinical study of minocycline-induced Pneumonitis. Intern Med. 1996; $35: 176-179$.

5. Sitbone O, Bidel N, Dussopt C, et al. Minocycline pneumonitis and eosinophilia. Arch Intern Med. 1994;154: 1633-1640.

6. 本多宣裕, 沖本二郎, 桜井 恵, 他. アガリクスによる薬 剂性肺炎の 1 例. 日胸. 2003;62:1027-1031.

7. Cooper JAD Jr, White DA, Matthay RA. Drug-induced pulmonary disease, part 1. Am Rev Respir Dis. 1986;133:321340.

8. Cooper JAD Jr, White DA, Matthay RA. Drug-induced pulmonary disease, part 2. Am Rev Respir Dis . 1986;133:488505.

9. Kay JM. Drug-induced lung disease. In: Hasleton PS, ed. Spencer's Pathology of the Lung. 5th ed. New York: McGraw Hill; 1996:551-595.

10. Akira M, Ishikawa H, Yamamoto S. Drug-induced pneumonitis: Thin-section CT findings in 60 patients. Radiology. 2002;224:852-860.

11. 安井正英, 藤村政樹. 薬剤誘起性呼吸器疾患の臨床一 DLST とチャレンジテストの意義一，日胸。2003;62:885891.

12. 近藤有好．薬剤による肺障害．結核．1999;74:33-41. 